\title{
A Two Year Serological Surveillance of Coronavirus Infections in Hamburg
}

\begin{abstract}
Summary: The occurrence of OC-43 coronavirus-like infections in the population of Hamburg was determined by a monthly serological survey (hemagglutination inhibition test [HI]) undertaken between October 1974 and October 1976. Studies of 3,016 sera revealed a high incidence of $\mathrm{HI}$ antibodies $(58.2 \%)$. The frequency of seropositive reactions $(=1: 8)$ and the geometric mean titer were higher in individuals 15 to 24 years old. Treatment of 50 positive sera (titer 1:16-1:64) with receptor destroying enzyme, kaolin and ethacridin for elimination of nonspecific inhibitors did not modify the HI-titer of the investigated sera. The serological seasonal pattern suggests that coronaviruses are circulating the whole year in the urban population with a prevalence in the fall-winter period. Of the 331 paired sera examined, $6.6 \%$ presented a four-to eightfold rise in titer within eight weeks.
\end{abstract}

Zusammenfassung: Eine serologische Untersuchung von Coronavirus-Infektionen in Hamburg über zwei Jahre. In der Zeit von Oktober 1974 bis 1976 wurde das Auftreten von OC-43 Coronavirus-ähnlichen Infektionen in der Hamburger Bevölkerung durch eine monatli. che serologische Untersuchung (HämagglutinationsHemmtest [HI]) überprüt. Untersuchungen an 3016 Seren zeigten eínen hohen Anteil von HI-Antikörpern $(58,2 \%)$. Die Häufigkeit von seropositiven Reaktionen $(=1: 8)$ und der geometrische Mittelwert-Titer waren bei Personen zwischen 15 und 24 Jahren am höchsten. Die Behandlung von 50 seropositiven Seren (Titer 1:16 -1:64) mit , receptor destroying enzyme" (RDE), Kaolin und Ethacridin zur Entfernung der unspezifischen Hemmfaktoren führte bei den untersuchten Seren zu keiner Veränderung der HI-Titer. Nach der serologisch bestimmten jahreszeitlichen Verteilung ist anzunehmen, daß Coronaviren das ganze Jahr uiber in der städtischen Bevölkerung zirkulieren - mit Bevorzugung der Herbst/Winter-Periode. Von den 331 geprüften Serumpaaren wiesen $6,6 \%$ einen vier-bis achtfachen Antikörper-Titeranstieg innerhalb von acht Wochen auf.

\section{Introduction}

Various surveillance programmes undertaken in recent decades have provided evidence that viral infection is the major identifiable cause of upper and lower respiratory tract disease in man.
As some cases did not appear to be linked with infections by known viruses, it was hoped that the human coronaviruses discovered relatively recently might account for a proportion of these unexplained illnesses.

That coronaviruses are potential respiratory pathogens has been demonstrated in experimental studies $(1,2)$. However, data on the extent and significance of infections by these viruses in human illnesses are still limited.

Serological surveillance carried out at regular intervals on a large number of sera taken from representative groups reveals the total infection rates (apparent and non-apparent) and the level and distribution of the seroimmunity in the population.

The following report of seroepidemiological studies of coronavirus infections is based upon observations made in the course of a surveillance programme in Hamburg (carried out since October 1974) in various sections of the population in which all age groups were represented.

\section{Material and Methods}

Population: A total of 3,016 blood samples was collected between October 1974 and September 1976 (minimum of 100 sera monthly) from "normal" healthy individuals divided into four age-groups: Group I ( 0 to 14 years old); Group II (15 to 24 years old); Group III ( 25 to 59 years old); Group IV (60 years old). We collected a second sample of blood two months later from 331 girls, 12 to 17 years old. After inactivation for 30 minutes at $56^{\circ} \mathrm{C}$, the sera were stored at $-20^{\circ} \mathrm{C}$ until used. All paired sera were tested simultaneously.

Antigen: Coronavirus strain OC-43 has been isolated by McIntosh et al. (3) in human embryo trachea organ culture from an adult with a cold. The strain was subsequently adapted to suckling mouse brain. Strain OC-43 antigen was prepared from infected suckling mouse brain according to the technique described by Kaye and Dowdle (4).

Serology: Hemagglutination inhibition (HI) tests were performed according to the Sever microtitre technique (5), using chicken red blood cells (4). Fifty positive sera (titre 1:16-1:64) were treated with receptor destroying enzyme (RDE) (6), kaolin (7) or ethacridin (8) for removal of nonspecific inhibitors.

\section{Results}

The incidence of seropositive reactions in the total population studied is presented in Table 1 . From the 3,016 sera investigated, 1,755 (58.2\%) showed HI antibody titres

Received: 30 May 1979

Prof. Dr. W. Ehrengut, Dr. D. E. Sarateanu, Institute for Vaccinology and Virology, D-2000 Hamburg 26, West Germany. 
Table 1: HI-Coronavirus antibodies in the population of Hamburg.

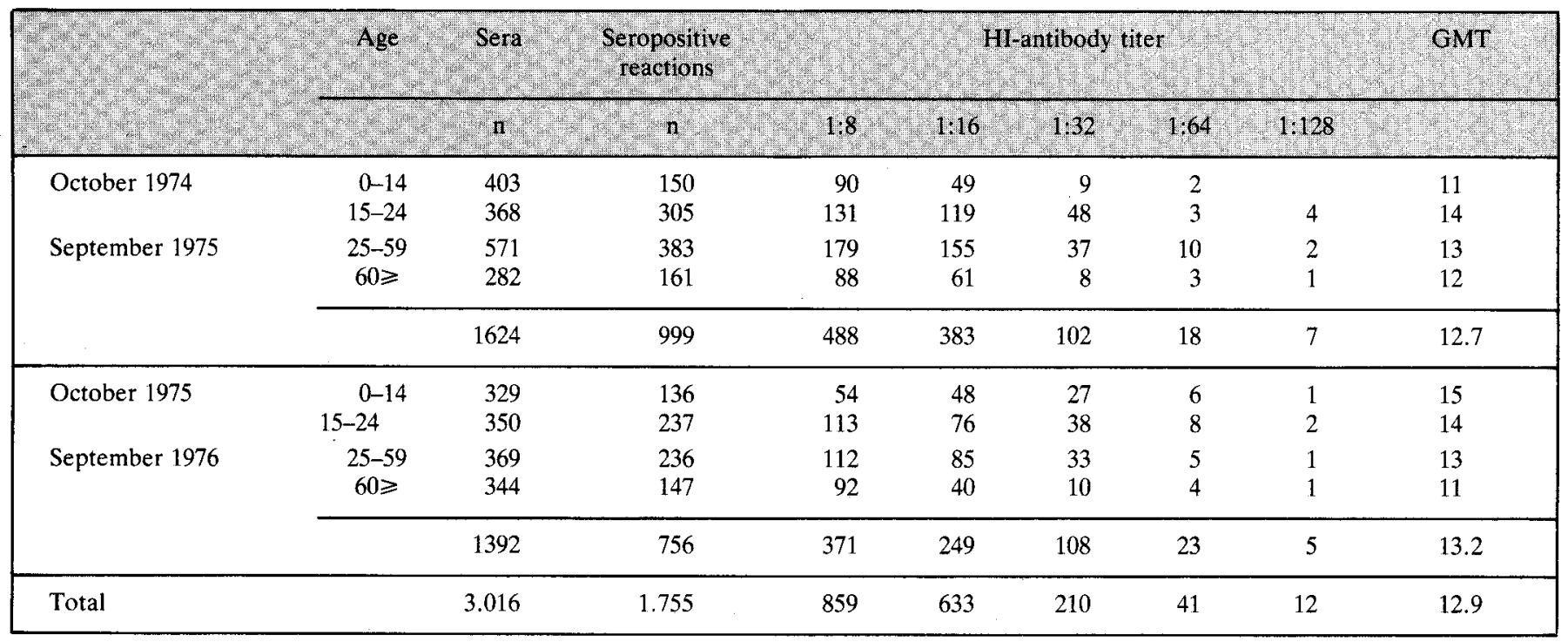

between 1:8 and 1:128. The geometric mean antibody titre (GMT) for the whole group was 1:12.8.

During the period extending from October 1974 to September 1975 the frequency of seropositive reactions in Group I (403 subjects) was $37.2 \%$ (GMT: 1:11), increasing in Group II (368 subjects) up to $82.9 \%$ (GMT: 1:14). In Group III (571 subjects) the percentage of seropositive individuals decreased to $67.1 \%$ (GMT: 1:13) and was markedly lower in Group IV (282 subjects) at $57.1 \%$ (GMT: 1:12).

In the following 12 months of surveillance (October 1975 to September 1976) the incidence of seropositive reactions in Group I (329 persons) increased to $41.3 \%$ (GMT: $1: 15)$ and dropped to $67.7 \%$ in Group II (350 persons). The values in Group III remained constant at $63.9 \%$ (GMT: 1:13) and fell to $42.7 \%$ (GMT: 1:11) in Group IV. Treatment of positive sera with RDE, kaolin or ethacridin did not modify the HI-titer of the 50 sera tested.

HI antibodies to coronaviruses were found in 280 individuals among 331 paired sera; a seroconversion with a four- to eightfold rise in titer occurred only in $22(6.6 \%)$. A twofold antibody increase was registered in a further 49 sera $(14.8 \%) ; 23$ individuals $(7.3 \%)$ showed a fall of the titers and in 186 persons $(56.2 \%)$ the titres remained unchanged (Table 2).
As far as the seasonal pattern is concerned, we observed frequent infections in November 1974; after that period the seroimmunity level of the population studied dropped continuously till June 1975 . An increased infection rate, with a peak in October to November 1975, was evident. From December 1975 to February 1976, the infection rates dropped markedly, followed by a smooth increase till the end of our present study in September 1976.

\section{Discussion}

Certain conclusions can be drawn from the data obtained during our two year surveillance period. Infections with human coronaviruses are common in all four groups studied, especially in Group II (15 to 24 years old).

The higher incidence of seropositive reactions in 15 to 24 year olds $(67.7 \%$ and $82.9 \%$, respectively) confirms our previous data $(9,10,11)$, those of Henigst (12), Monto and $\operatorname{Lim}(13)$, and Riski and Estola (14) who also found a higher percentage of seropositive reactions in the 15 to 19 year old group $(12,13)$ and in individuals of 21 to 50 years (14).

Considering the results obtained in Group I and II, our data are in agreement with those of Kaye and Dowdle (15). The higher level of coronavirus antibodies and the

Table 2: HI-Coronavirus antibodies in paired sera (Hamburg 1974 to 1976).

\begin{tabular}{|c|c|c|c|c|c|c|c|c|c|c|c|}
\hline \multirow{2}{*}{$\begin{array}{l}\text { Age } \\
\end{array}$} & \multirow{2}{*}{$\frac{\text { Paired sera }}{n}$} & \multicolumn{2}{|c|}{$\begin{array}{l}\text { Seropositive } \\
\text { reactions }\end{array}$} & \multicolumn{2}{|c|}{ Constant HI-titer } & \multicolumn{2}{|c|}{ Declining HI-titer } & \multicolumn{4}{|c|}{ Rising HI-titer } \\
\hline & & $\mathrm{n}$ & $\%$ & $\mathrm{n}$ & $\%$ & n & $\%$ & $2 x$ & $\%$ & $4 \times$ & 8 \\
\hline & 131 & 95 & 72.5 & 53 & 40.4 & 9 & 6.9 & 25 & 19.1 & 8 & 6.1 \\
\hline $12-17$ & 200 & 185 & 92.5 & 133 & 66.5 & 14 & 7 & 24 & 12.1 & 14 & 7 \\
\hline Total & 331 & 280 & 84.6 & 186 & 56.2 & 23 & 6.9 & 49 & 14.8 & 22 & 6.6 \\
\hline
\end{tabular}


higher incidence of seropositive reactions found in Group II may be attributed to multiple infections and to a special susceptibility of the group. These data also indicate an increased spread of coronaviruses in this segment of the population. The percentage of seropositive reactions in Group I ( 0 to 14) was smaller than that found in other groups. An explanation of this situation may be found in the data provided by McIntosh et al. (16): they suggested that in infants coronaviruses play a smaller role in the etiology of lower respiratory tract diseases.

The lower rate of seropositive reactions could also mean that the virus is weakly antigenic in children. Since preschool children are also included in Group I, this may explain the rate of seropositive reactions. It is known that in preschool children infections with OC-38 and OC-43 coronaviruses are predominant whereas infections with strain $229 \mathrm{E}$ are prevalent in adults (17).

The seasonal pattern suggests that coronaviruses are circulating the whole year in the urban population, with prevalence in the cold season, a decrease in the warm season and sporadic cases at other times of the year. Other authors $(13,17,18,19)$ also found coronavirus infections usual in the period January to April. In our study we observed peaks in November 1974, October to November 1975, and in September 1976, followed by low infection rates in the spring-summer season. Similar data

\section{Literature}

1. Bradburne, A. F., Bynoe, M. L., Tyrrell, D. A. J.: Effects of a "new" respiratory virus in volunteers. Br. Med. J. 3 (1967) $767-769$.

2. Tyrrel, D. A. J., Bynoe, M. L.: Cultivation of a novel type of common-cold virus in organ cultures, Br. Med. J. 1 (1965) 1467-1470.

3. McIntosh, K., Dees, J. H., Becker, W. B., Kapikian, A. Z., Chanock, R. M.: Recovery in tracheal organ cultures of novel viruses from patients with respiratory disease. Proc. Natl. Acad. Sci. 57 (1967) 933-940.

4. Kaye, H. S., Dowdle, W. R.: Some characteristics of hemagglutination of certain strains of "IBV-like" virus. J. Infect. Dis. 120 (1969) $576-581$.

5. Sever, J. L.: Applications of a microtechnique to viral serological investigations. J. Immunol. 88 (1962) 320-329.

6. U.S.A. Department of Health, Education and Welfare: Advanced laboratory techniques for influenza diagnosis. Public Health Service Atlanta 1975, p. 26.

7. U.S.A. Department of Health, Education and Welfare: Laboratory diagnosis by serologic methods. Public Health Service Atlanta 1973, D-28.

8. Heide, K., Haupt, H.: Darstellung noch nicht therapeutisch angewandter Plasmaproteine. Behring-Werke Mitteilungen 43 (1964) 161-192.

9. Sarateanu, D., Bronitki, A., Popescu, A., Teodosiu, O., Isala, G.: Incidence of Coronavirus OC 43 antibodies among the population of Rumania. Rev. Roum. Virol. 25 (1974) 255-258.

10. Sarateanu, D. E., Ehrengut, W.: Serological study of coronavirus antibodies in Hamburg. Immun. Infekt. 3 (1975) 86-88.

11. Sarateanu, D. E., Ehrengut, W.: Jahreszeitliche Schwankungen were published by Bradburne and Somerset (20), and by McIntosh et al. (16).

We may assume that in the peak periods Hamburg witnessed a wave of infection caused by an OC- 43 virus or a related virus.

Neither the number of human respiratory types nor the extent of their serological cross-reactivity are well known as far as coronaviruses are concerned. It is known however that several members cross-react in one or more types of serological tests and that heterotypic antibody rises occur (21).

As we did not isolate coronaviruses in our patients and in view of the possibility of heterologous responses of the antibody titers that we have found, we cannot interpret them as being specifically due to the OC- 43 virus alone. The antibody response found in this seroepidemiological survey may be an expression either of past or present infections or reinfections with an agent identical or closely related to the antigen used in the test. Reinfections with coronaviruses are not a rare event considering that over $50 \%$ of the titer rises encountered in the 331 paired sera occurred in individuals with prior antibodies. The high rates of seropositive reactions provide complete evidence that coronaviruses are circulating widely in the urban population of Hamburg.

von Koronavirusinfektionen in Hamburg. Immun. Infekt. 4 (1976) 141-143.

12. Henigst, $\mathbf{W} .:$ Occurrence of antibody against coronavirus (OC43) in the healthy population and in patients with a disease of the respiratory tract. Zbl. Bakteriol. I. Abt. Orig. A 299 (1974) 150-158.

13. Monto, A. S., Lim, K. S.: The Tecumseh study of respiratory illness. VI Frequency of and relationship between outbreaks of coronavirus infection. J. Infect. Dis. 129 (1974) 271-276.

14. Riski, H., Estola, T.: Occurrence of antibodies to human coronavirus OC43 in Finland. Scand. J. Infect. Dis, 6 (1974) 325-327.

15. Kaye, H. S., Marsh, H. B., Dowdle, W. R.: Seroepidemiologic survey of coronavirus (Strain OC 43) related infections in a children's population. Am. J. Epidemiol. 94 (1971) 43-49.

16. McIntosh, K., Kapikian, A. Z., Turner, H. C., Hartley, J. W., Parrott, R. H., Chanock, R. M.: Seroepidemiologic studies of coronavirus infection in adults and children. Am. J. Epidemiol. 91 (1970) 585-592.

17. Hamre, D., Beem, M.: Virologic studies of acute respiratory disease in young adults. V. Coronavirus $229 \mathrm{E}$ infections during six years of surveillance. Am. J. Epidemiol 96 (1972) 94-106.

18. Hendley, J. O., Fishburne, H. B., Gwaltney, J. M. jr.: Coronavirus infections in working adults, eight-year study with $229 \mathrm{E}$ and $\mathrm{OC} 43$. Am. Rev. Respir. Dis. 105 (1972) 805-811

19. Kapikian, A. Z., James, H. D. jr., Kelly, S. J., Dees, J. H., Turner, H. C., McIntosh, K., Kim, H. W., Parrott, R. H., Vincent, M. M., Chanock, R. M.: Isolation from man of "avian infectious bronchitis virus-like" viruses (coronaviruses) similar to $229 \mathrm{E}$ virus, with some epidemiological observations. J. Infect. Dis. 119 (1969) 282-290.

20. Bradburne, A. F., Somerset, B. A.: Coronavirus antibody titres in sera of healthy and experimentally infected volunteers. J. Hyg. (Lond.) 70 (1972) 235-244.

21. Bradburne, A. F.: Antigenic relationship amongst coronaviruses. Arch. ges. Virusforsch. 31 (1970) 352-364. 